\title{
Geology
}

\section{Proterozoic mantle lithosphere beneath the extended margin of the South China block: In situ Re-Os evidence}

\author{
Kuo-Lung Wang, Suzanne Y. O'Reilly, William L. Griffin, Sun-Lin Chung and Norman J. Pearson \\ Geology 2003;31;709-712 \\ doi: $10.1130 / G 19619.1$
}

Email alerting services

Subscribe

Permission request click www.gsapubs.org/cgi/alerts to receive free e-mail alerts when new articles cite this article

click www.gsapubs.org/subscriptions/ to subscribe to Geology

click http://www.geosociety.org/pubs/copyrt.htm\#gsa to contact GSA

Copyright not claimed on content prepared wholly by U.S. government employees within scope of their employment. Individual scientists are hereby granted permission, without fees or further requests to GSA, to use a single figure, a single table, and/or a brief paragraph of text in subsequent works and to make unlimited copies of items in GSA's journals for noncommercial use in classrooms to further education and science. This file may not be posted to any Web site, but authors may post the abstracts only of their articles on their own or their organization's Web site providing the posting includes a reference to the article's full citation. GSA provides this and other forums for the presentation of diverse opinions and positions by scientists worldwide, regardless of their race, citizenship, gender, religion, or political viewpoint. Opinions presented in this publication do not reflect official positions of the Society.

\section{Notes}




\title{
Downloaded from geology.gsapubs.org on 19 September 2009
Proterozoic mantle lithosphere beneath the extended margin of the South China block: In situ Re-Os evidence
}

\author{
Kuo-Lung Wang* $\quad$ Australian Research Council National Key Centre for the Geochemical Evolution and Metallogeny of \\ Suzanne Y. O'Reilly - Continents (GEMOC), Department of Earth and Planetary Sciences, Macquarie University, NSW 2109, \\ Australia \\ William L. Griffin Australian Research Council National Key Centre for the Geochemical Evolution and Metallogeny of \\ Continents (GEMOC), Department of Earth and Planetary Sciences, Macquarie University, NSW 2109, \\ Australia, and CSIRO Exploration and Mining, North Ryde, NSW 2113, Australia \\ Sun-Lin Chung Department of Geosciences, National Taiwan University, Taipei 106, Taiwan, Republic of China \\ Norman J. Pearson Australian Research Council National Key Centre for the Geochemical Evolution and Metallogeny of \\ Continents (GEMOC), Department of Earth and Planetary Sciences, Macquarie University, NSW 2109, \\ Australia
}

\begin{abstract}
The Os isotope compositions of sulfides in mantle xenoliths from the Penghu Islands, Taiwan Strait, reveal the presence of Proterozoic subcontinental lithospheric mantle beneath the highly extended southeast margin of the South China block. Both $T_{\mathrm{RD}}$ (Re depleted) model ages for individual sulfides and model ages estimated from the initial ${ }^{187} \mathrm{Os} /{ }^{188} \mathrm{Os}$ ratios of $\mathrm{Re}-\mathrm{Os}$ mixing lines require that some volumes of the subcontinental lithospheric mantle formed prior to 2.3-1.9 Ga. Later events in the subcontinental lithospheric mantle may be recorded by $T_{\mathrm{RD}}$ model ages of 1.5-1.2 Ga and ca. $0.9 \mathrm{Ga}$. The events recognized in the subcontinental lithospheric mantle are consistent with those known in the crust of the mainland South China block. The sulfide Os isotope data show that Proterozoic lithosphere beneath the South China block has survived the extensive Mesozoic Yanshanian magmatism on the continental margin and has not been delaminated even during the severe lithospheric extension that led to the subsidence of the Taiwan Strait.
\end{abstract}

Keywords: lithospheric mantle, Re-Os, sulfides, Taiwan Strait, Proterozoic, South China block.

\section{INTRODUCTION}

The continents are underlain by roots of subcontinental lithospheric mantle that vary in thickness, composition, and thermal state depending on the age and tectonothermal history of the overlying crust (e.g., O'Reilly et al., 2001, and references therein). Most undisturbed Archean (older than $2.5 \mathrm{Ga}$ ) cratonic areas have thick (180-250 km deep) subcontinental lithospheric mantle keels. However, the breakup and reassembly of continents through time suggests that these keels can be disrupted or thinned, as in active rift zones and passive-margin situations. These mechanisms are poorly understood in detail, and new tools that can track mantle volumes through these processes are needed.

Whole-rock Re-Os isotope data from mantlederived peridotites have contributed much information on the age of the subcontinental lithospheric mantle (Shirey and Walker, 1998; Pearson, 1999). However, recent studies have demonstrated that Os in these rocks is concentrated in sulfide phases and that these can be mobile within the subcontinental lithospheric mantle, so that whole-rock Re-Os model ages probably reflect mixing processes,

*E-mail: kwang@els.mq.edu.au. rather than single melting events (Alard et al., 2002; Griffin et al., 2002b). Recent developments in the in situ analysis of the Re-Os system in sulfide phases allow us to unravel some of this complexity and improve the interpretation of the age information contained in the mantle-derived samples (Pearson et al., 2002; Alard et al., 2002; Griffin et al., 2002b). The mobility of Os within the subcontinental lithospheric mantle also may provide new insights into the timing and processes of metasomatism in the subcontinental lithospheric mantle.

Studies of mantle xenoliths from Paleozoic kimberlites and Cenozoic basalts in the North China craton suggest that a thick, cool, and depleted Archean subcontinental lithospheric mantle was largely replaced by a thin, hot, and fertile subcontinental lithospheric mantle in late Mesozoic to early Cenozoic time (Griffin et al., 1998; Gao et al., 2002). Relicts of the Archean lithosphere, preserved locally at shallower levels, coexist with fertile Phanerozoic subcontinental lithospheric mantle beneath the eastern part of the North China craton (Zheng et al., 2001). Detailed seismic tomography (Yuan, 1996) suggests that the Archean subcontinental lithospheric mantle was disrupted by extension (a brittle failure model) and that asthenospheric material has welled up between the relict blocks.

Scattered xenolith data and seismic tomography suggest that the eastern part of the Proterozoic South China block is underlain by thinner and less depleted subcontinental lithospheric mantle than the western part (e.g., $\mathrm{Xu}$ et al., 2000). Here we present in situ Re-Os isotope data for sulfides in mantle xenoliths from the Penghu Islands, in the Taiwan Strait (Fig. 1). These data demonstrate the survival of ancient subcontinental lithospheric mantle beneath the extended margin of the South China block, which underwent widespread late Mesozoic magmatism, followed by lithospheric extension and crustal subsidence.

\section{GEOLOGIC BACKGROUND AND SAMPLE DESCRIPTIONS}

The South China block is composed of the Yangtze craton in the northwest and the $\mathrm{Ca}$ thaysian fold belts (Cathaysia), including the Cenozoic mountain ranges of Taiwan, in the southeast (Fig. 1). The Yangtze craton has a Late Archean-Paleoproterozoic $(1.7 \mathrm{Ga}$ or older) nucleus surrounded by late Mesoproterozoic orogenic belts; the Cathaysia block is floored by Paleoproterozoic to Mesoproterozoic continental crust (Chen and Jahn, 1998, and references therein). The eastern Cathaysia block was strongly affected by the late Mesozoic Yanshanian bimodal magmatism. Eastern China has undergone extension due to the late Mesozoic subduction of the paleo-Pacific plate beneath Eurasia and/or the Indo-Eurasia collision since the early Paleogene. Along the continental margin, this extension led to the formation of early Tertiary basins, and subsidence of the Taiwan Strait accompanied the opening of the South China Sea (Chung et al., 1994). Meanwhile, widespread intraplate basaltic volcanism (65 Ma to Holocene; Fig. 1), some carrying abundant mantle-derived xenoliths, has occurred in these basins in conjunction with the regional extension.

The xenoliths discussed here come from 


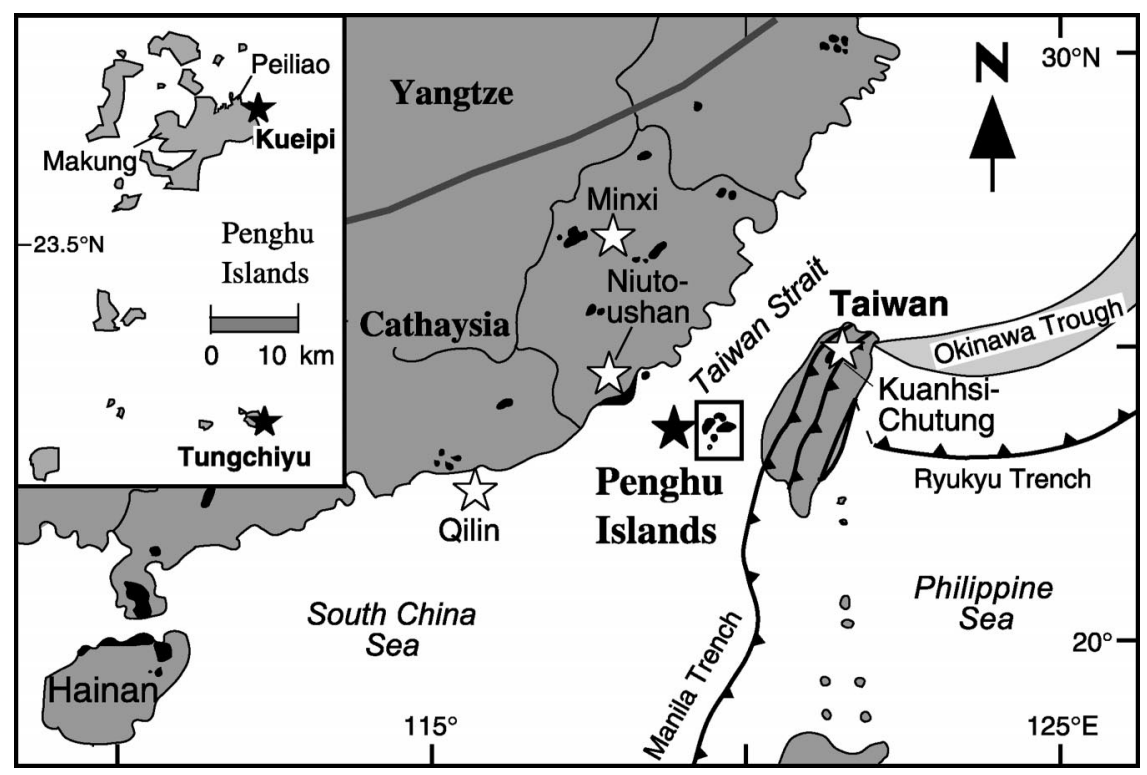

Figure 1. Tectonomagmatic map of southeastern China. Black areas-late Cenozoic intraplate basalts; stars-localities of mantle xenoliths; solid star-locality of xenoliths in this study. Inset: main sample localities in Penghu Islands.

two localities in the Penghu Islands in the Taiwan Strait: Kueipi in the main island and the Tungchiyu islet (Fig. 1). The islands are made up of Miocene alkaline and tholeiitic basaltic lavas (16-8 Ma; Chung et al., 1994). The Kueipi xenoliths are 13 to $10 \mathrm{Ma}$ (Lee, 1994) alkali basalt flows. The Tungchiyu xenoliths are from a pyroclastic layer (13.2-11.2 Ma; Ho et al., 2000) in the lower sequence. The xenoliths are dominantly spinel peridotites with minor spinel pyroxenites. At least two episodes of metasomatism are reflected in the fluid-inclusion distributions and the trace element patterns of clinopyroxenes. The range of observed compositions indicates that the lithospheric mantle beneath this region is a mixture of moderately refractory and fertile lherzolites, similar to mantle xenolith suites from several mainland localities (Xu et al., 2000). Like these suites, they are compositionally distinct from oceanic peridotites (Griffin et al., 1999) and their olivine contents and Fo values $^{1}$ fall off the "oceanic peridotites" trend of Boyd (1989).

Sulfides $\geq 50 \mu \mathrm{m}$ across were analyzed in polished thin sections of peridotites and pyroxenites. Most sulfides are interstitial, but some are enclosed in olivine. Element-distribution maps derived from electron-microprobe imaging in this study show that nearly all sulfide grains from Kueipi consist of interfingered $\mathrm{Ni}$-rich and Fe-rich monosulfide solid solutions

${ }^{1}$ GSA Data Repository item 2003100, Table DR1, in situ Re-Os data of Penghu sulfides, Taiwan, and Figure DR1, plot of Mg-number versus modal olivine of host peridotites, is available from Documents Secretary, GSA, P.O. Box 9140, Boulder, CO 80301-9140, editing@geosociety.org, or at www. geosociety.org/pubs/ft2003.htm.
(MSS), with an outer rim of chalcopyrite. Those from Tungchiyu mostly have Fe-rich MSS cores, surrounded by Ni-rich MSS and a Co-rich rim. There is no convincing difference between enclosed and interstitial sulfides in terms of their major and trace element composition in either locality.

\section{ANALYTICAL METHODS}

Analytical procedures and the precision and accuracy of the method for in situ Re-Os isotope analysis were described in detail by Pearson et al. (2002) (also see www.es.mq.edu.au/ GEMOC). Analyses were carried out in $\mathrm{He}$, using a Merchantek LUV266 laser microprobe with a modified ablation cell, attached to a $\mathrm{Nu}$ plasma multicollector inductively coupled plasma-mass spectrometer (ICP-MS) at Macquarie University, Sydney. A synthetic NiS bead spiked with a known Os isotope composition (PGE-A) was used for calibration of the instrument.

\section{RESULTS AND DISCUSSION \\ Metasomatism and Interpretation of Model Ages}

Alard et al. (2000, 2002) argued that silicateenclosed sulfides may represent MSS residual from melting processes in the subcontinental lithospheric mantle, whereas interstitial sulfides are the crystallization products of sulfide-bearing metasomatic fluids. Most Penghu sulfides are interstitial and therefore may represent secondary metasomatic events, rather than primary melt-depletion events in the subcontinental lithospheric mantle. Because sulfide melts have low melting points and viscosities, in the same range as volatile-rich melts (Gaetani and Groves, 1999), they are likely to be mobile in the subcontinental lithospheric mantle. Thus, once a metasomatic melt and/or fluid formed, sulfides might move with such fluids through the subcontinental lithospheric mantle, to be precipitated as interstitial phases. They would become enclosed if trapped by later recrystallization and grain growth (Griffin et al., 2002b). Metasomatism may have been continuous or episodic ever since the subcontinental lithospheric mantle first was isolated from the convecting part of the mantle, and the sulfide data thus are most likely to date metasomatic events; however, such ages would provide minimum estimates for the age of the subcontinental lithospheric mantle.

Estimated Os contents of the analyzed sulfides range from 5 to $110 \mathrm{ppm}$ (median 16 ppm) (see footnote 1). Most Penghu sulfides have subchondritic ${ }^{187} \mathrm{Os} /{ }^{188} \mathrm{Os}$ ratios $(<0.1249)$ that preclude the possibility that the interstitial sulfides represent host-rock contamination; alkali basalts typically have ${ }^{187} \mathrm{Os} /{ }^{188} \mathrm{Os}>0.135$ (Shirey and Walker, 1998). Griffin et al. (2002b) suggested that sulfides with ${ }^{187} \mathrm{Re} /{ }^{188} \mathrm{Os}>0.07-0.08$ may have undergone significant disturbance of their Os isotope systematics, and only those grains with lower ratios could yield realistic model ages of separation from the chondritic mantle $\left(T_{\mathrm{MA}}\right)$. The Penghu sulfides mostly have ${ }^{187} \mathrm{Re} /{ }^{188} \mathrm{Os}$ ratios ranging from 0.12 to 1.07 , and $T_{\mathrm{MA}}$ model ages derived from such sulfides may be meaningless in terms of subcontinental lithospheric mantle age. Two sulfides with low ${ }^{187} \mathrm{Re} /{ }^{188} \mathrm{Os}$ ratios $(0.063$ and $0.025)$, both from Tungchiyu, yield $T_{\mathrm{MA}}$ ages of $2.28 \pm 0.38 \mathrm{Ga}$ (TC0242/2-S6; peridotite) and $0.92 \pm 0.16 \mathrm{Ga}$ (TC0223-S3; pyroxenite) (see footnote 1). Despite the high Re/Os ratios of Penghu sulfides, their model ages for Re depletion $\left(T_{\mathrm{RD}}\right)$ will still provide minimum estimates of subcontinental lithospheric mantle age. The $T_{\mathrm{RD}}$ model ages of the 17 sulfides with the best analytical precision range from 2.6 to $0.7 \mathrm{Ga}$ (Fig. 2E) and indicate that many of the samples have resided in the subcontinental lithospheric mantle at least since Proterozoic time.

The presence of both positive and negative correlations in Figure 2 strongly suggests that all of the correlations represent mixing lines and that the positive correlations do not have age significance. The three enclosed sulfides (S5, S6, and S8) in Kueipi peridotite sample KP0215 with the lowest analytical uncertainty define an age of $1424 \pm 440 \mathrm{Ma}$ and initial ${ }^{187} \mathrm{Os} /{ }^{188} \mathrm{Os}$ ratio of $0.1116 \pm 0.0023(2 \sigma$; MSWD [mean square of weighted deviates] = 0.13 ; Fig. 2A). The $T_{\mathrm{RD}}$ model ages of these three sulfides range from 1.52 to $1.13 \mathrm{Ga}$ (see footnote 1). If the correlation line is treated as a mixing trend, it has an end member with a 

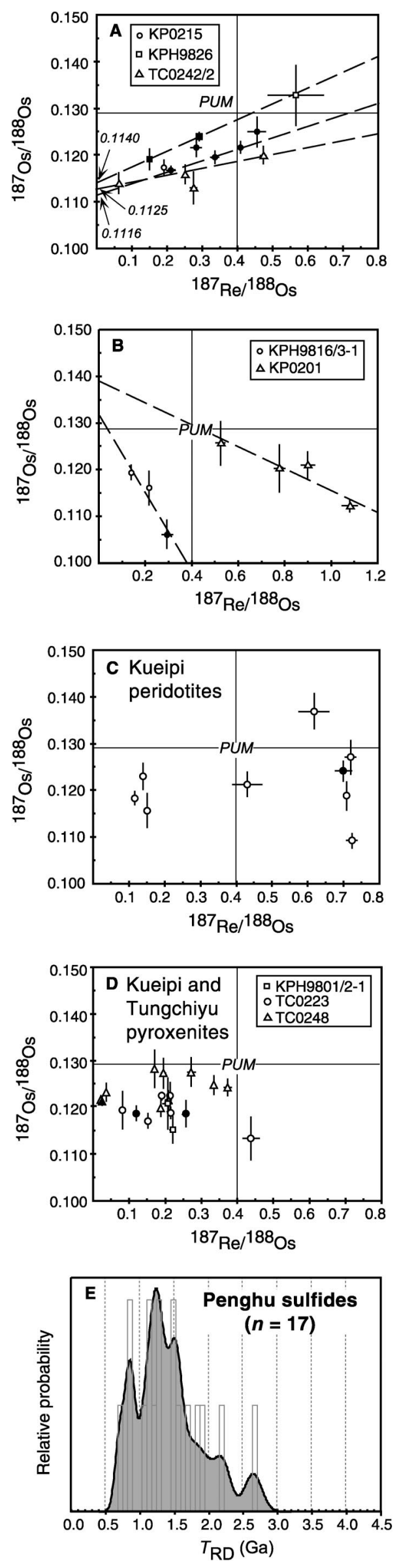

Figure 2. Plots of ${ }^{187} \mathrm{Os} /{ }^{188} \mathrm{Os}$ vs. ${ }^{187} \mathrm{Re} /{ }^{188} \mathrm{Os}$ for sulfides. Error bars shown in A-D are $\pm 2 \sigma$. A: Sulfides from Kueipi and Tungchiyu show positive correlation trends. B: Sulfides from Kueipi show negative correlation trends. C: Other sulfides from Kueipi peridotites. D: Sulfides from Kueipi and Tungchiyu pyroxenites. Solid symbols represent enclosed sulfides; open symbols represent interstitial sulfides. PUM-primitive upper-mantle values (Meisel et al., 2001). $\mathrm{E}: T_{\mathrm{RD}}$ (Re depletion) model ages. seen in sulfides from the Kueipi and Tungchiyu pyroxenites, whose range of ${ }^{187} \mathrm{Re} /{ }^{188} \mathrm{Os}$ is 0.025-0.439 (Fig. 2D), but whose $T_{\mathrm{RD}}$ ages vary from 1.48 to $0.7 \mathrm{Ga}$. The Os isotope compositions clearly are not related to timeintegrated in situ ${ }^{187}$ Re decay, and the sulfides apparently were subjected to recent Re addition. The combination of high $\mathrm{Re} / \mathrm{Os}$ ratios with relatively unradiogenic Os implies that the Re-bearing metasomatic fluid and/or melts, if they carried Os, came from a reservoir with low Re/Os ratios. The most likely candidate for this reservoir is the surrounding ultramafic subcontinental lithospheric mantle.

In summary, sulfides from Penghu peridotites and pyroxenites have recently undergone three types of disturbance in their Os isotope systematics: (1) addition of Re with no apparent addition of Os, or with only lithospheric Os with low ${ }^{187} \mathrm{Os} /{ }^{188} \mathrm{Os}$ ratios; (2) addition of $\mathrm{Re}$, and of Os with an isotope composition near the present-day PUM; (3) addition of radiogenic Os, but little or no Re. The highly radiogenic Os in disturbance type 3 could be derived from lithospheric sources such as pyroxenites or subducted basalts, and the transporting medium may have been an oxidizing fluid derived from the Mesozoic subducting slab beneath the area.

Processes 2 and 3 involve the introduction of Os that is radiogenic relative to that expected in old subcontinental lithospheric mantle; in this case, neither $T_{\mathrm{MA}}$ nor $T_{\mathrm{RD}}$ model ages may date specific events, except perhaps in the case of rare sulfides having low Re/Os ratios (Griffin et al., 2002b). However, $T_{\mathrm{RD}}$ model ages will still provide minimum estimates for the age of the subcontinental lithospheric mantle, whether the sulfides originally were residual from melt-depletion events or were deposited from metasomatic fluids derived from the asthenosphere. The $T_{\mathrm{RD}}$ model ages of the Penghu sulfides with the best analytical precision range from 2.64 to $0.70 \mathrm{Ga}$, with a major peak between 1.5 and $1.2 \mathrm{Ga}$ (Fig. 2E), and the $T_{\mathrm{RD}}$ model ages derived for the component of the mixing lines having low Re/Os ratios (Fig. 2B) are all in the range 2.3$1.9 \mathrm{Ga}$.

These data require that parts of the subcontinental lithospheric mantle beneath the Taiwan Strait have been segregated from the convecting mantle since at least Middle Proterozoic time, and some parts may have formed as early as the Late Archean.

\section{Tectonic Implications}

$\mathrm{U}-\mathrm{Pb}$ dating of zircons from basement rocks in northwestern Fujian and southwestern Zhejiang Provinces gives minimum ages of 1.77 $\mathrm{Ga}$ for the Cathaysia block crust (Li, 1996). No Proterozoic crustal ages have been reported from the coastal Fujian-Taiwan region, 
which is totally overprinted by the Yanshanian magmatic activity related to Mesozoic subduction and extension. However, Sm-Nd model ages $\left(T_{\mathrm{DM}}\right)$ of Yanshanian granites (Chen and Jahn, 1998) and Hf model ages of zircons from such rocks (Griffin et al., 2002a) indicate that lower crust at least 1.8-0.9 b.y. old existed beneath the region. Li et al. (2002) reported $1.43 \mathrm{Ga}$ granodiorites from Hainan Island in southern Cathaysia. These ages might link crustal formation at $1.5-0.9 \mathrm{Ga}$ in the Fujian-Taiwan coastal margin and the 1.4 $\mathrm{Ga}$ transcontinental magmatism in southern Laurentia (Nyman et al., 1994).

Our sulfide age data indicate that at least part of the subcontinental lithospheric mantle beneath the thinned margin of the Cathaysia block is as old as some crust in its interior and survived the Yanshanian magmatism and subsequent extension and crustal thinning. The similarity in the range of crustal $\mathrm{Nd}$ and $\mathrm{Hf}$ model ages and our sulfide $T_{\mathrm{RD}}$ ages (Fig. 2E) suggests that the sulfide ages may actually date metasomatic events in the subcontinental lithospheric mantle, related to mantle thermal events that affected the lower crust.

Most mantle xenoliths in Tertiary basalts from the South China block are relatively fertile, suggesting that the old Proterozoic lithosphere beneath it has been largely replaced by younger mantle, probably during late Mesozoic to Cenozoic time. However, some strongly depleted xenoliths also suggest that older lithospheric-mantle material persists in the lithosphere beneath the southeastern China region (Xu et al., 2000). Our Os isotope data from the mantle beneath the Taiwan Strait further support this scenario. Relicts of the subcontinental lithospheric mantle, older than upper crust in the region, have survived both lithospheric replacement and Cenozoic lithospheric thinning and extension. This observation is directly relevant to the question of whether the delamination (or convective removal; e.g., Houseman et al., 1981) of Archean or Proterozoic subcontinental lithospheric mantle is possible. The mixture of ancient (refractory) and younger (fertile) peridotites suggests that the Proterozoic subcontinental lithospheric mantle is not simply the thinned upper part of the subcontinental lithospheric mantle, underlain by fertile younger material. A model involving brittle failure of the lithosphere during extension, with upwelling of asthenospheric material into tensional zones (mushroom cloud model; Yuan, 1996), would explain the mixture observed here. Delamination mechanisms may be most relevant to regions with denser Phanerozoic subcontinental lithospheric mantle (Poudjom Djomani et al., 2001).

\section{ACKNOWLEDGMENTS}

We thank Carol Lawson, Suzy Elhlou, and Stuart Graham for assistance with the analytical facilities and Ming Zhang, Chi-Yu Lee, Jin-Hui Yang, and Kung-suan Ho for help in the field work and useful discussion. The manuscript was improved by thoughtful reviews from Simon Turner, Robyn Hannigan, and Ben A. van der Pluijm. This is Australian Research Council National Key Centre for the Geochemical Evolution and Metallogeny of Continents (GEMOC) publication 319. Funding was provided by the Australian Research Council, Macquarie University, and the Ministry of Education, Taiwan.

\section{REFERENCES CITED}

Alard, O., Griffin, W.L., Lorand, J.P., Jackson, S.E., and O'Reilly, S.Y., 2000, Nonchondritic distribution of the highly siderophile elements in mantle sulfides: Nature, v. 407, p. 891-894.

Alard, O., Griffin, W.L., Pearson, N.J., Lorand, J.P., and O'Reilly, S.Y., 2002, New insights into the Re-Os systematics of subcontinental lithospheric mantle from in situ analysis of sulfides: Earth and Planetary Science Letters, v. 203, p. 651-663.

Boyd, F.R., 1989, Compositional distinction between oceanic and cratonic lithosphere: Earth and Planetary Science Letters, v. 96, p. 15-26.

Brandon, A.D., Creaser, R.A., Shirey, S.B., and Calson, R.W., 1996, Osmium recycling in subduction zones: Science, v. 272, p. 861-864.

Chen, J., and Jahn, B.-M., 1998, Crustal evolution of southeastern China: $\mathrm{Nd}$ and $\mathrm{Sr}$ isotopic evidence: Tectonophysics, v. 248, p. 101-133.

Chung, S.L., Sun, S.-s., Tu, K., Chen, C.-H., and Lee, C.Y., 1994, Late Cenozoic basaltic volcanism around the Taiwan Strait, southeast China: Product of lithosphere-asthenosphere interaction during continental extension: Chemical Geology, v. 112, p. 1-20.

Gaetani, G.A., and Groves, T.L., 1999, Wetting of mantle olivine by sulfide melt: Implications for $\mathrm{Re} / \mathrm{Os}$ ratios in mantle peridotite and late stage core formation: Earth and Planetary Science Letters, v. 169, p. 147-163.

Gao, S., Rudnick, R.L., Carlson, R.W., McDonough, W.F., and Liu, Y.-S., 2002, Re-Os evidence for replacement of ancient mantle lithosphere beneath the North China craton: Earth and Planetary Science Letters, v. 198, p. 307-322.

Griffin, W.L., O’Reilly, S.Y., Ryan, C.G., Gaul, O., and Ionov, D., 1998, Phanerozoic evolution of the lithosphere beneath the Sino-Korean craton, in Flower, M.F.J., et al., eds., Mantle dynamics and plate interactions in East Asia: American Geophysical Union Geodynamics Series, v. 27, p. 107-126.

Griffin, W.L., O'Reilly, S.Y., and Ryan, C.G., 1999, The composition and origin of subcontinental lithospheric mantle, in Fei, Y., et al., eds., Mantle petrology: Field observations and high-pressure experimentation: A tribute to Francis R. (Joe) Boyd: Houston, Texas, Geochemical Society Special Publication 6, p. 13-45.

Griffin, W.L., Wang, X., Jackson, S.E., Pearson, N.J., O'Reilly, S.Y., Xu, X., and Zhou, X., 2002a, Zircon chemistry and magma mixing, SE China: In-situ analysis of $\mathrm{Hf}$ isotopes, Tonglu and Pingtan igneous complexes: Lithos, v. 61, p. $237-269$.

Griffin, W.L., Spetsius, Z.V., Pearson, N.J., and O'Reilly, S.Y., 2002b, In situ Re-Os analysis of sulfide inclusions in kimberlitic olivine: New constraints on depletion events in the Siberian lithospheric mantle: Geochemistry, Geophysics, Geosystems, v. 3, p. 1069.

Ho, K.-S., Chen, J.-C., Smith, A.D., and Juang, W.S., 2000, Petrogenesis of two groups of pyroxenites from Tungchiyu, Penghu Islands,
Taiwan Straits: Implication for mantle metasomatism beneath southeast China: Chemical Geology, v. 167, p. 355-372.

Houseman, G.A., McKenzie, D.P., and Molnar, P.J. 1981, Convective instability of a thickened boundary layer and its relevance for the thermal evolution of continental convergent belts: Journal of Geophysical Research, v. 86, p. 6115-6132.

Lee, C.Y., 1994, Chronology and geochemistry of basaltic rocks from Penghu Islands and mafic dikes from east Fujian: Implications for the mantle evolution of southeast China since late Mesozoic [Ph.D thesis]: Taipei, National Taiwan University, $243 \mathrm{p}$

Li, X.H., 1996, Timing of the Cathaysia block formation: Constraints from SHRIMP U-Pb zircon geochronology: Episodes, v. 20, p. $188-192$.

Li, Z.X., Li, X.H., Zhou, H.W., and Kinny, P.D., 2002, Grenvillian continental collision in south China: New SHRIMP U-Pb zircon results and implications for configuration of Rodinia: Geology, v. 30, p. 163-166.

Meisel, T., Walker, R.J., Irving, A.J., and Lorand, J.P., 2001, Osmium isotopic compositions of mantle xenoliths: A global perspective: Geochimica et Cosmochimica Acta, v. 65, p. 1311-1323.

Nyman, M.W., Karlstrom, K.E., Kirby, E., and Graubard, C.M., 1994, Mesoproterozoic contractional orogeny in western North America: Evidence from ca. 1.4 Ga plutons: Geology, v. 22, p. 901-904.

O'Reilly, S.Y., Griffin, W.L., Poudjam Djomani, Y.H., and Morgan, P., 2001, Are lithospheres forever? Tracking changes in subcontinental lithospheric mantle through time: GSA Today, v. 11 , p. 4-10.

Pearson, D.G., 1999, The age of continental roots: Lithos, v. 48, p. 171-194.

Pearson, N.J., Alard, O., Griffin, W.L., Jackson, S.E., and O'Reilly, S.Y., 2002, In situ measurement of Re-Os isotopes in mantle sulfides by laser ablation multicollector-inductively coupled plasma mass spectrometry: Analytical methods and preliminary results: Geochimica et Cosmochimica Acta, v. 66, p. 1037-1050.

Poudjom Djomani, Y.H., O'Reilly, S.Y., Griffin, W.L., and Morgan, P., 2001, The density structure of subcontinental lithosphere: Constraints on delamination models: Earth and Planetary Science Letters, v. 184, p. 605-621.

Shirey, S.B., and Walker, R.J., 1998, The Re-Os system in cosmochemistry and high temperature geochemistry: Annual Review of Earth and Planetary Sciences, v. 26, p. 423-500.

Xu, X., O'Reilly, S.Y., Griffin, W.L., and Zhou, X., 2000 , Genesis of young lithospheric mantle in southeastern China: An LAM-ICPMS trace element study: Journal of Petrology, v. 41, p. 111-148.

Yuan, X.C., 1996, Velocity structure of the Qinling lithosphere and mushroom cloud model: Science in China, ser. D, v. 39, p. 235-244.

Zheng, J.P., O'Reilly, S.Y., Griffin, W.L., Lu, F., Zhang, M., and Pearson, N.J., 2001, Relict refractory mantle beneath the eastern North China block: Significance for lithospheric evolution: Lithos, v. 57, p. 43-66.

Manuscript received 20 February 2003

Revised manuscript received 21 April 2003

Manuscript accepted 24 April 2003

Printed in USA 